\title{
12
}

\section{Combatting corruption in the Philippine Customs Service}

\author{
Guillermo Parayno, Jr.
}

In the 1970s and 1980s, the Philippine Customs Service undertook anticorruption campaigns to combat the perceived defects in the inherent character of the Customs personnel. They used a combination of negative reinforcement, value formation, and attitudinal change which have all been found to be ineffective. The programs entailed the establishment of specialised government watchdog, investigative and prosecution agencies against corruption. Generally, however, all ended up being the same tools of the corrupt practitioners against the government officials whose mission it was to combat this social malady.

On the other hand, recent programs, implemented from 1992-98, had as their focus the reengineering of the environment within which customs officers operate. By reducing the opportunities for corruption, heightening the risk for committing corrupt acts, and reducing the rewards thereof, they achieved better results in curbing, if not totally eliminating, negative bureaucratic behaviour. In the reengineering process, information technology was employed as the essential tool for lifting customs administration into the realm of electronic governance.

There are, however, limits to the effectiveness of these environmental approaches to combating corruption in customs. The most significant and real limitation was that the measures were perceived by Customs itself as external temporary stopgap impositions to be supported only when their main patron was still occupying the seat of power. The leadership recognised this and designed contingencies to ensure sustainability of the reform. The business sector was extensively involved in the reform process and was repeatedly made aware that the responsibility of ensuring continuity rested upon them. To date, this 'friendly force' is still responding to the challenge and is helping to ensure that the reform program does not become a brief shining moment in the history of the Philippine Customs Service. 


\section{Public perceptions of the Customs Service}

The general impression that the Philippine Customs Service is one of the most corrupt government agencies dates back to the time of Spanish colonial rule.

More recently, in August 1990, the Social Weather Station-the most reliable survey agency-conducted a survey on the perceived extent of corruption in a number of government agencies. The Bureau of Customs was viewed as the most corrupt agency, with 74 per cent of respondents considering the extent of corruption to be large ( 24 per cent perceived the level to be small and 1 per cent had no opinion). In the same survey report, Customs ranked alongside the police force in registering the lowest margin of satisfaction-negative 49 per cent (dissatisfied 56 per cent; satisfied 7 per cent; undecided 36 per cent) —on the issue of actions in place to reduce corruption (Dayag and Laylo 1994:2).

Many published reports show huge customs revenue losses due to corruption. The extent of smuggling in the Philippines is widely believed to be between 12.2 per cent and 53 per cent of recorded imports. Figures from the IMF's Direction of Trade Statistics (1990) show that, at 11.59 per cent, the Philippine has the second highest level, after Thailand, of import undervaluation as a percentage of total imports.

In a privilege speech before the House of Representatives, a Congressman reported that for a six month period alone (first half of 1992), an estimated one billion pesos ( $\$ 37$ million) in duties and taxes were lost by government from goods either diverted or illegally withdrawn from Customs Bonded Warehouses. Over 100 such warehouses were involved and were closed accordingly.

\section{The nature and causes of corruption in Customs}

Many factors predispose the Customs Service to a high incidence of corruption. Almost all of these are environmental in nature rather than inherent defects or flaws in the character of the Customs officers. It is only fitting, therefore, that the anticorruption programs be focused on addressing these environmental factors, but without neglecting the psychological underpinnings of corrupt acts. The more important contributors to the incidence of corruption in the Customs Service are as follows.

\section{Abundant opportunities}

This is the single most important cause of widespread corruption in Customs. About 1.5 million import entries, the same number of export entries, 200,000 requests for goods transfers, 500,000 liquidations of raw material 
imports, 500,000 bond applications and tens of thousands of other transactions (duty drawback, accreditation, accountability clearances, licenses renewals, and so on) are filed each year. Face to face interaction in these transactions is essential owing to complex and bureaucratic procedures exacerbated by the still restrictive and complex foreign trade regime. This provides fertile ground for corruption. Opportunities for corruption are as numerous as the total number of transactions, which is easily 4 million. Multiplying this by the number of processing stations - which, conservatively, is 10yields a potential 40 million opportunities for corruption each year. Special mention must be given to the many exemption laws and the absence of clear guidelines and procedures for the grant of such exemptions. Billions of pesos have been lost to syndicates and their conspirators through the granting of undeserved or questionable exemptions and refunds.

\section{Irresistible rewards}

The legitimate salary of Customs officers pales in comparison to the rewards they receive from their corrupt practices. Smugglers share their profits with their conspirators and, since the profits are magnified by the high tax and tariff walls and the inflationary valuation method, the attraction is almost irresistible. Even legitimate business is disposed to giving attractive rewards because the cost of the delay in the clearance of goods can be more than the financial cost of illegally accelerating the process. Although the majority of businessmen would want to deal with the government above board, many are forced to pursue illegal channels and methods in order to stay in business.

\section{Low-risk endeavour}

In addition, insurance is often provided by smuggling syndicates to their conspirators in government. Conniving officials are provided the best legal counsel money can buy and, in the rare case that one is found guilty, he or she is well provided for during his incarceration.

\section{Damaged values system and culture}

'Everyone is doing it!' There is pressure to do what everybody else is doing. Even before a Customs officer joins the organisation, he or she already has the preconception that corruption is a ticket to riches. This is confirmed on entering the organisation. There is practically no indignation against corruption in Customs, probably because it is perceived as an open crime without a victim, and hence not considered much of an offence. Professionalism is utterly lacking in the Customs Service. The organisation offers its staff very little in terms of status and pride in being part of the organisation. 
There is also the 'live and let live' culture and the code of omerta or silence. Officials and businessmen who are unwilling to live by these rules are subjected to discrimination, and are even ostracised.

\section{Weak controls and justice system}

There is a dire need for effective systems that make it difficult for officials to engage in corrupt practices and make detection of corrupt acts more likely. The chance of being found guilty after being caught is also low due to ineptness and corruption in the justice system. All these factors encourage officials to behave in a corrupt manner. Syndicates even offer insurance to their conspirators in government by footing the cost of their defence and taking care of their families while they are undergoing investigation, trial, or serving punishment.

\section{Lack of means and support}

Many men and women who join the organisation do so with the right ideals, but they quickly realise that sincerity and dedication alone are not enough. For example, they may strongly suspect that a shipment is undervalued or that it is wrongly classified but since they are not technically trained or equipped to prove this, they may ignore it. The easiest thing is to go along with everybody else.

\section{Insincere and opportunistic media}

Many in the media are using their facilities to share in the fruits of corruption instead of performing their role as neutral observers in a democratic society. Their modus operandi ranges from threats, coercion and intimidation through media exposure to blatant participation in illegal activities. Unfortunately, corrupt officials have no difficulty keeping these media practices alive. It is just considered an additional expense.

\section{Typical acts of corruption}

\section{Being or threatening to be difficult}

These are actions not involving the commission of a criminal act. They may involve threatening to take actions, under the guise of performing official duty, that would create difficulties to the subject of the action, such as the issuance of Alerts, Hold Orders and Mission Orders; Submission of Derogatory Information; Recommendation to Stop the Operations; Uplifting of Values, or sending the shipment for laboratory examination; requiring additional supporting documents, such as a CRF, price list or product brochure. 
They may involve the threat of submitting derogatory reports (valid or otherwise) that could create difficulties for the subject of the report, or of submitting exaggerated assessments/audit findings coupled with recommendations for punitive measures as a means to extort certain sums.

Further, they could involve delaying initiation or completion of official action until a favour is given or promised. For example, attending to those who have given favour first; being absent when the requested action is much needed; prolonging hearings in seizure cases; conducting detailed examinations; asking for documents that are difficult to produce.

\section{Sins of omission}

This includes not performing one's duty in order to give favour. Examples would be not acting on violations that come to one's attention; dereliction of duty, such as when an examiner does not conduct examination of a smuggled shipment or releases the same notwithstanding the violations observed; officers who allow goods to be illegally withdrawn; customs guards who allow shipments to be removed without the duties and taxes having been paid; hearing officers deciding a case in favour of the offender.

\section{Direct participation in criminal activities}

These acts are the most risky but also the most rewarding. Examples include assisting the introduction of spurious documents leading to fraudulent release of a shipment; grant of a license to operate a CBW (radio) which is clearly to be used as a conduit for smuggling; non-remittance of collections or delayed remittance coupled with the illegal placement of the fund; pilferage of goods from security warehouses, shipments or public bonded warehouses.

\section{Previous initiatives to curb corruption}

Previous initiatives were mainly focused on the customs personnel-their shortcomings, weaknesses and vulnerabilities. Underpinning these initiatives was the belief that acts of corruption spring from a character defect or lack of moral fibre. Thus, anticorruption activities were centred on establishing specialised offices and agencies which were charged with altering the character of a customs official through punishment or threat, as well as through value formation and attitudinal change programs.

Large-scale investigations, prosecutions and purges had limited effect, and many of those who were removed from the service managed to rejoin the organisation through their connections to officers with power. The legal proceedings that attended the dismissal procedures only served to drain top management's strength and time. Some effort was taken to reduce the 
opportunities for corruption by streamlining the cargo clearance process and by limiting the number of signatories to the clearance documents, but the initiatives failed.

\section{Martial law and the dictatorship years}

Common knowledge that the Customs Bureau was one of the most corrupt government agencies was probably the reason that it was one of the first to undergo large-scale purges during the early days of the Martial Law Years (1972-86). On 29 September 1972, seven days after the declaration of martial law, some 200 senior customs officers were dismissed by the President (244 if those performing customs-related functions in other offices in the Department of Finance are included). This was followed on 1 November 1972 by a second wave of dismissals involving some 111 senior personnel. These two purges cleared out more than 8 per cent of the Bureau's workforce.

The 1972 purges also took place in several other government offices and formed part of the nationally-implemented emergency measures, such as the midnight to dawn curfew, the warrantless arrests and seizure orders, the operation of military tribunals, the assignment of military supervisors in sensitive government offices and the campaign against loose firearms. For a short while they had a positive impact in reducing the level of corruption in government, including the Customs Bureau.

By 1976, it became clear that the impact of the emergency measures had waned-particularly in Customs-prompting a third wave of purges. The impact of this was even more short-lived.

In 1977, faced with a return to the old ways-so-called 'backsliding'the President appointed for the first time a military man as head of Customs. The new Commissioner brought with him a small number of young, highly educated military officers who later assumed sensitive positions in the Intelligence, Investigation and Police departments of Customs. They also assumed leadership in the two most sensitive ports, the Port of Manila and the Manila International Airport.

The tenure of the military officers saw the introduction of a number of initiatives against bureaucratic corruption, albeit on a limited scale. Cargo clearance procedures were simplified not only to remove the system's vulnerability to fraud and also reduce the number of steps and signatories required to complete the process. The system remained fully manual, however, and all transactions went through the same 'one size fits all' clearance procedure. The result was that new steps crept in almost as quickly as other steps were removed by management. Consequently, the opportunities for corruption remained widespread. 
The nine-year military administration did produce significant results in restricting fraud against government revenue. This was partly because there was much opportunity at the time for engaging in illegal trade and the rewards were substantial. Tariffs were high and were placed on many essential consumer and producer commodities. Coupled with very tight foreign exchange controls, these 'incentives' pushed a significant segment of trade underground.

While the success of the military leadership in the fight against corruption was noteworthy, it was the economic restructuring undertaken by the national government in the 1980s that laid the foundation for the gradual reduction of the rewards and opportunities for fraud against Customs revenue. The two major reforms instituted-the Tariff Reform Program and the Import Liberalisation Program-were not actually even intended as anticorruption measures.

\section{The revolutionary government years}

The change of government following the February 1986 People's Power Revolution, which toppled the 14-year old dictatorship, sparked a renewed effort to rid society of graft and corruption. Initially, the campaign was limited to information drives such as poster displays in government offices calling for an end to graft and corruption in government. Subsequently, a program based on the theory that corruption thrives most in an environment where the rewards are high and the risks low was launched. Responsibility for this national anticorruption program rested upon a national committee called the Public Ethics and Accountability Committee (PEAC). Spearheaded by the Development Academy of the Philippines, PEAC Task Forces were established for each Department and measures were implemented to reduce the rewards and opportunities for corruption as well as heightening the risk of detection. In the Customs Service, several orders were issued limiting the level of control officials had over the clearance of goods, as a means of reducing corruption in the Bureau.

Actual government behaviour deviated from this progressive view of fighting corruption, particularly at the Customs Bureau. As with the Martial Law Years, over 300 customs personnel-many of them senior officerswere purged under the guise of reorganising the Bureau. Concerned officials challenged the legality of the purges in court. The ensuing legal battles, which went all the way to the Supreme Court, effectively prevented the customs leadership from making significant headway in its anticorruption campaign.

While measures were initiated to streamline the cargo clearance process, to limit the number and participation of law enforcement agencies, and to 
curtail the discretion of customs personnel in assessment, these measures were too little and too late to make any significant dent on corruption. The overall result was disappointing, particularly since reputable surveys showed that the Customs Bureau and the national police were the two most corrupt government agencies by mid 1992 .

\section{National government agenda to curb corruption, 1992-98}

The three national anticorruption programs of the Ramos Administration were the Moral Recovery Program (MRP), the Resident Ombudsman Program, and the Presidential Commission Against Graft Commission.

\section{The Moral Recovery Program (MRP)}

The MRP became established on 18 September 1987 when the Senate passed Resolution No. 10 on the urgent need for an MRP and decided to inquire into the strengths and weaknesses of the Filipino character with a view towards solving social ills and strengthening the nation's moral fibre. It became a national program on 30 September 1992, when Presidential Proclamation No. 62 was issued declaring an MRP and enjoining active participation of all sectors in Filipino society.

The aim of MRP was to strengthen those values and attitudes in society that would make it difficult for corruption to persist. One particular prescription in the program was to establish a more efficient bureaucracy, with a minimum of red tape. The focus of the drive, however, remained the individual and the means was value formation.

\section{The Presidential Commission Against Graft and Corruption}

The Presidential Commission Against Graft and Corruption, a three-man special commission, was to investigate administrative complaints against presidential appointees in the executive department, including those in government-owned and controlled corporations. It was a failure, and was actually utilised by syndicates to file harassment charges against government officials who were forcefully doing their work and hurting the syndicates in the process.

\section{The Resident Ombudsman Program}

Resident ombudsmen were assigned to several sensitive government agencies. A significant drop took place in the number of cases filed against officials of the agencies where there was a resident ombudsman. It is not clear, however, whether the presence of resident ombudsmen contributed to a reduction in corruption cases filed or if the program actually contributed to a reduction in the level of corruption. 


\section{Customs Anticorruption Program, 1992-98}

The common focus of all three national government programs was the individual. The array of measures were likewise similar-investigations and prosecutions supplemented by behaviour modification through value formation. As Professor Jon Quah of the National University of Singapore pointed out during the 1999 Manila ADB/OECD Workshop on Combating Corruption, however, the Philippines has had the greatest number of these anticorruption agencies. Because of what he termed a 'lack of political will', these and similar initiatives in the past have not been effective in curbing corruption. Experience shows, however, that negative bureaucratic behaviour will continue, irrespective of strong political will for change, as long as the customs officer continues to work in the same poor environment.

\section{General principles and strategies}

The Customs leadership under the Ramos Administration had a running start in its anticorruption program. A Blueprint for Customs Development for the Year 2000 was immediately drafted in consultation with many interested parties (organisations and individuals), both in the business sector and in government. The document analysed the changing environment within which the organisation will operate in the coming years. It defined the demands on Customs from the government, the business community, and the rest of society. It anticipated the realities or constraints that the Customs Service faced. Finally, the environment of the Customs Service was examined for opportunities that could be harnessed to support the developmental thrust. Only after that were the objectives clearly determined and the general strategies for the attainment of such objectives laid down.

Particular care was taken to make the document look more like a development plan than an anticorruption program. This was done to gain the organisation's support for the plan. The only reference to corruption in the plan was a general statement that a "climate that promotes involvement, commitment, integrity and professionalism shall be cultivated'.

\section{Reengineering of the Customs environment}

The main philosophy underlying the Customs Service anticorruption program from 1992-98 was the same as during President Aquino's tenurereducing the rewards to corruption, emphasis on reducing the opportunities for, and increasing the risks of, engaging in corrupt acts. During this period, however, there was a massive reengineering of the environment in the Customs Service. 
With information and other technologies as essential enablers, customs systems and procedures and the work environment were re-engineered with the goal of attaining

- full automation of the processes (no officer intervention) for 80 per cent of transactions, with the percentage to be gradually increased to 95 per cent

- repositioning of controls to where they are most effective without obstructing business and trade (before goods arrival and after their release), as well as the removal of queues and choke points

- provision of remote lodgment facilities to enable the public to interact with the organisation without the need for face-to-face interactions

- complete paperless and cashless processes

- privatisation of certain operations

- electronic linkage of all the participating agencies in the system

- the development of clear and simple rules.

\section{Measures addressing systemic weaknesses and vulnerability to fraud}

To ensure that revenue generation is not sacrificed while bureaucratic corruption is being addressed, short and long-term revenue enhancement programs were set in place to remove system weaknesses and vulnerabilities as follows.

- Concerned private sector associations were empowered, enabling early detection of violations as they police violations within their own ranks.

- Friendly and constructive competition was encouraged among the various law enforcement units.

- Extensive information and encryption technology was introduced into the electronic transmission and utilisation of payments, release instructions, exemptions and other sensitive data.

- Advanced technology, such as a global positioning system, was introduced to allow tracking and accounting of transit cargo.

- Customs warehouses, container yards, freight stations and other customs facilities used as conduits for smuggling were closed, and the regulations for the licensing of new facilities were tightened. 
- The auditing process was strengthened.

- Investigation, prosecution and hearing offices were strengthened.

\section{Electronic governance}

Electronic governance is the creative application of information technology in government operations to allow more effective delivery of services to the citizenry. Information technology was applied extensively in a range of Customs operations.

\section{Collection system}

Project Abstract Secure. Project Abstract Secure ended the losses in Customs revenues arising from the introduction of spurious payment documents in payment abstracts and official receipts delivered to Customs by the bank's couriers.

The project was conceived after the discovery in 1992 of shipments released with the use of spurious bank documents by a syndicate in collusion with bank and Customs personnel. Estimated losses of duties and taxes ran into hundreds of millions of dollars.

The main feature of Project Abstract Secure is the use of security software in the encryption of payment data by the agent banks, their transmission to the Bureau in an electronic form, and their decryption at the Bureau offices. The software provides a highly sophisticated data security system and cryptographic algorithms to protect data and prevent unauthorised access to sensitive information. Data cannot be decrypted without a smart card and the cryptographic keys. The transmission process was overhauled and only electronic card-bearing personnel from the Bureau can gain access to the system. The Bureau also developed a feedback process designed to catch break-ins in case the security system is breached.

Automated collection from special accounts. Raw material imports for Customs manufacturing warehouses are released without duties and taxes but are charged fees. Prior to the reform, five separate fees were collected by five different collecting officers. These were the cost-of-entry forms, documentary stamps, processing fees, boatnote and overtime charges. The face-to-face interaction at each of these payment stations presented opportunities for extracting grease money and creating delays in the clearance process. Further, problems were discovered in the handling of these collections, with cashiers running away with their collections to 'kiting' operations (collections are placed in high yield financial instruments in the name of the collecting officer instead of being immediately remitted to the Treasury).

Under this reform, manufacturing companies open up special accounts in an in-house Customs bank from which the above fees are electronically 
debited. The greatest benefit is the speed of the electronic processing. In addition, the various illegal practices of collecting officers were curtailed as these officers no longer handle cash. A further benefit to the Customs Service is that some companies make payments up to three months in advance to ensure they have sufficient credit from which their payments can be debited. Mandatory payment to the authorised agent banks and in-house banks. Prior to this reform, only shipments covered by letters of credit were required to pay duty and tax through the banks. Taxes for the majority of shipments were paid directly to Customs collecting offices. As with the payment of the various fees for warehousing entries described above, a number of anomalies were discovered in the direct payments to Customs. Spurious checks took place, and cheques were often diverted to other accounts.

Under the reform, mandatory payments of duties and taxes had to be made to the banks for all shipments as the first step in the clearance process. As a convenience for those living far from Customs House, in-house banks were established in each district port with computer workstations directly connected to the Customs port servers. With this reform, Customs collection operations became paperless and cashless, thus eliminating many of the anomalies arising from a collection system which was based on cash and cheque payments and where payments documents were handled by numerous staff. Projects Reconcile 1 and 2. Electronic filing of payments under the computerised collection system made possible the replacement of the old manual system of reconciling payments collected by the banks and bank remittances to the National Treasury with an electronic reconciliation process. The manual process typically had a four-month backlog, whereas the electronic reconciliation process can be completed within a day. Thus, agent banks that fail to remit any collection are immediately detected and penalised. Under Project Reconcile 1, the amounts collected by the banks and electronically transmitted to the Bureau under Project Abstract Secure are matched with the amounts actually remitted to the National Treasury through the Bangko Sentral.

Under Reconcile 2, the electronic files of payments, with which the assessments are compared prior to the release of the goods, are regularly compared with the Central Headquarters filex that received directly from the banks. This can show whether tampering of electronic records occurred at the ports.

\section{Declaration processing}

Automated Customs Operating System. The implementation of this main Customs operating software drastically changed the processing of clearance documents and declarations. Under the system, Customs works with the 
electronic record of a clearance document, thus rendering the process virtually paperless. With electronic declarations, the entire process has been fully automated for most of the transactions from entry reception to assessment, collection, and release of the goods. Record-keeping and the generation of both operational and management reports have likewise been automated.

Remote lodgement of declarations. The electronic record can be created and lodged by the importer himself through computer workstations linked to the Customs network. Following the Direct Trader Input (DTI) procedure or the alternative Electronic Data Interchange (EDI) procedure, importers can file declarations from their own office. Under the DTI system, importers make use of the declaration module of the main Customs software to compose the declaration and then lodge it electronically by establishing a direct connection with the Bureau's computer system. Under EDI, declarations composed in the EDIFACT message format are likewise electronically lodged, but via a commercial communication network. From there, the message is forwarded to a gateway which converts the message into a data declaration stream that the Customs system can process.

Private sector operated service centres. Importers who are not capable of using either DTI nor EDI must go through service centres operated by the Philippine Chamber of Commerce and Industry. Through these facilities, the declarations are digitised and then electronically transmitted to the port computer system for automated processing. As with DTI and EDI, there is no face-to-face interaction between an importer and a customs officer in the service centres, thus removing opportunities for corruption at this stage of the Customs clearance process.

Risk assessment, selectivity and green lanes. At the heart of the Automated Customs System is a computer program called Selectivity. It analyses the risk profiles of shipments and categorises them as high, medium or low risk by comparing their particulars with some 18 reference tables and files. Low-risk shipments are diverted by the computer system to a Green Channel where the only activity undertaken is the automated calculation of tax payable and matching of the calculated amount with the amount paid. Only when the declaration is considered to be of high risk is it necessary to conduct a physical examination and a verification of submitted documents.

These interrelated measures represent a shift in strategy for reducing corruption-from reducing the number of steps and signatures required in the process to reducing the number of transactions. These measures allow customs authorities to focus limited enforcement resources on a manageable number of shipments and thus allow greater depth of Customs intervention. Just as important is the application to the majority of trade, to reduce the cost and extent of corruption. 
Customs-cargo handler computer systems interface in the release of goods (Online Release System). One of the weakest links in the cargo clearance chain is the handover of the cargo release authority from Customs to the cargo handler. This stage of the cargo clearance process is where spurious release documents usually appear. In most cases, investigations to pinpoint responsibility for the introduction of such documents and the fraudulent release of goods are unsuccessful.

The first version of the initiative to address this weak link was the Online Release System (OLRS). This system facilitates and makes secure the final release of shipments from Customs control. For the in-dock OLRS, Customs is connected online to the cargo handler for the simple matter of removing a stop flag and for red channel shipments, the lowering of the examination flag. The off-dock OLRS utilises the public telephone system to download the encrypted release instructions to the computers of the container yard-container freight station, located away from the ports. The off-dock OLRS removes the need for messengers to physically carry the release authorisations. In the past, traffic congestion in the metropolis meant that authorisations took at least a day to deliver. Fraud and corruption frequently took place in the physical handling of the release authorisations by messengers.

Unfortunately, the first version of the OLRS had weaknesses. OLRS clerks were commonly given spurious matching documents and fraudulently lifting the duty stop. The release procedure has subsequently been strengthened further. The results of the computer matching of payables and payments are automatically downloaded into a communications gateway from which the cargo handler computer can draw release authorities. With this interface, the entire process from reception to assessment and collection and thence to cargo release has become seamless.

\section{Tax exemption system}

The manual system for issuing and transmitting tax exemptions has been breached many times, resulting in the introduction of fictitious or tampered exemption papers and fraudulent release of shipments. The solution adopted was to computerise the receipt and processing of exemption applications at the Department of Finance and to provide a secure electronic communication channel for transmitting the approved exemptions to Customs. The work flow system, on top of a lease lines network, removed many if not all of the weaknesses and vulnerabilities of the operation. Now that the notes can be encrypted, the process is secure and has been dramatically shortened - much to the delight of the business community. 


\section{Use of VTS to secure the transfer of cargo}

A highly political issue in Customs corruption involves the control of goods in transit from the various ports of entry to the special economic zones (SEZs), most notably to the former American military bases of Subic and Clark. Domestic producers and manufacturers have drawn attention to the diversion of goods destined for these SEZs as a source of competing smuggled goods. Since the use of guards has not worked, vehicle tracking using global positioning system technology has been put in place. The movement of goods is tracked via computers and reported on a real time basis in order that emergency response teams can take immediate action in case of diversions.

\section{Customs Service-Federation of Philippine Industry Data Link-up}

The Federation of Philippine Industry Data Link is a partnership between the government and the private sector to enforce Customs laws. It is also a showcase for the provision of easy access to Customs data for businesses. Through this data link, business is able to access records of sensitive imports as they enter the system so that an analysis can be immediately undertaken as to possible violations committed. Cases of undervaluation, and even misclassification, can be detected through this link-up. The objective is to establish a level playing field and bring about transparency in the conduct of business.

\section{Results and lessons learned}

The overall results of the ACI were positive for the Bureau and for the country. The achievements were also recognised internationally by such prestigious organisations as the World Customs Organisation, UNCTAD and by numerous customs administrations and customs regional groupings.

Probably the best testimony to the success of the 1992-98 anticorruption program is the passion and commitment with which the business sector and other concerned groups-including many in the executive and legislative areas of government-are now fighting to preserve the gains captured during the period. There is also strong support from such international organisations as UNCTAD, the International Monetary Fund and the World Bank. The Asian Development Bank in Manila also showed its appreciation for the gains produced, by organising symposium workshops on the reforms.

Following the 1998 national elections, the new administration not only slowed the reform process but caused setbacks for some components of the program. The Direct Trader Input system at the Ninoy Aquino International Airport was discontinued for almost a year and was resumed only after the business sector-particularly the Semiconductor and Electronics Industry 
Federation Inc.-and other private sector groups strongly pushed for its resumption. The business sector, led by the Philippine Chamber of Commerce and Industry and the Federation of Customs Brokerage Companies of the Philippines, is strongly advocating the removal of manual procedures that have been added to the once fully-automated and paperless system.

The experience of the Philippine Customs Service shows that anticorruption initiatives that promote good governance and provide a working environment with limited opportunity for corrupt practices are most effective in bringing about a significant reduction in the incidence of this social malady. Experience also indicates that the successes and difficulties encountered in implementation of these initiatives were strongly influenced by a number of factors, some of which were within the ambit of management influence and control.

\section{Leader's role}

The most important determinants of the success of an anti-corruption program are related to the extent to which the leader 'owns' the program and displays 'hands-on' management. He or she can demonstrate these qualities by participating in the design, development, implementation, and monitoring of the project, and by dealing with the problems encountered. Also important are the rewards and recognition given to those contributing to the success of the program and the sanctions meted out to those who refuse to cooperate. Perhaps most important, however, is leadership by example - the extent to which he or she actualises the program and conducts himself, officially and unofficially, throughout the program.

\section{Private sector role}

The business sector can be the Customs Service's strongest ally in the development and execution of the initiatives. While material and technological support are important, the private sector can be of most help in change management and sustainability. Efforts must be made to involve the CEOs of businesses affected by the program. They must ensure that their own organisations work with the Bureau on the various components of the program, instead of simply relying on 'representatives' and 'agents'. They are the ones in contact with the top government officials and are hence in the best position to impress upon them the necessity and value of the reforms and the need for continuity and sustainability. The private sector must be vigilant and courageous in demanding improved services and higher ethical standards from government civil servants. Customs management must protect them, and it must be made known to the internal staff that it is policy to encourage the private sector to speak its mind on the reforms. 


\section{Role of the IMF, World Bank and other international organisations}

At times, donor and international organisations are more forceful than the private sector in calling for vigilance, sustainability and continuity in the reform program. In undertaking an assessment of their respective projects that directly or indirectly relate to the anticorruption initiatives, these organisations must objectively report any deviations from the program. Managers of the reform process must be able to work with these institutions to ensure continuity.

\section{Negative reinforcement}

While it is highly desirable to obtain support and commitment for the anticorruption program from the formal and informal leadership in the organisation, it is not realistic to expect real commitment and support when the organisation's interest is not properly aligned with the program objectives.

\section{Audit}

Related to the readiness to apply negative reinforcers is the need for strong monitoring and auditing of the reform progress. The leadership must make use of external assistance in this activity, given the propensity of internal staff to fail to present an objective picture of the level of corruption and to cover up for one another. It is desirable to have an independent auditing unit reporting directly to the top leadership. The business sector should also endeavour to conduct their own surveys to provide independent feedback.

\section{Resource availability}

In bringing about reforms, availability or adequacy of resources is not the issue. The issue is availability of sectors concerned or interested in the need for the reform. If there are enough concerned groups, there will be enough resources.

Some factors are beyond the control of the reform managers and are better addressed at the national policy level. Complex tax and tariff systems which create many rate bands and exemptions and entail numerous non-tariff barriers, such as licenses, approvals, quotas and permits, make for complicated administration and create opportunities for corruption. The Philippine government is aware of the ill-effects of such a policy framework and has done much to improve the situation, particularly on tariff and tax reforms. But stronger political will is required to ensure that vested interest groups do not jeopardise the positive things that have been accomplished in previous years. 